\title{
In Memoriam: \\ With Halil Hoca at the Quads of the University of Chicago
}

Fariba Zarinebaf* - Linda Darling**

Palmira Brummett***-Daniel Goffman****

It is a great honor to be able to pay tribute to the immense achievements of a great scholar, teacher, and mentor whose enormous intellectual energy and depth of knowledge have made a lasting impact on the field of Ottoman-Middle Eastern studies as well as world history.

Professor İnalcık transformed the field of Ottoman studies from an obscure and exotic sub-field into one of the leading historical disciplines that covers the history of the greater Middle East and North Africa as well as the Balkans from the late medieval to the modern period. He set the tone of debate and critical inquiry from the early modern to the modern period. Very few leading historians of these fields have failed to read and engage the scholarship of Professor Inalckk. His own scholarship covers a broad expanse of territory, from the history of Crimea, Albania, and Anatolia in the fifteenth century to Bulgaria in the nineteenth century. His works on the Ottoman land tenure system, taxation, trade, and provincial administration remain crucial for any serious scholar who is trying to tackle these issues in a specific space and time. Young scholars from the Balkans, the Middle East and Turkey seldom take issue with the primary findings of Professor İnalckk and instead try to build on his works. He has set the agenda for a critical analysis and understanding of a crucial time period in world history. Professor İnalcık has engaged leading historians like Fernand Braudel and

* Fariba Zarinebaf (Associate Professor of History, University of California-Riverside)

** Linda Darling (Professor of History, University of Arizona, Tucson)

*** Palmira Brummett (Visiting Professor of History, Brown University)

**** Daniel Goffman (Emeritus Professor of History, DePaul University) 
Immanuel Wallerstein. His ability to grasp and understand the leading debates in European history as well as world history and his attempts to incorporate these debates into Ottoman history by responding to these scholars in a constructive manner is inspiring in a discipline where regionalism and national boundaries are often dominant and limiting.

Professor İnalcık's works on the origins of the Ottoman Empire, the rise of the Beylikate, and state formation built on the works of his mentors, Fuad Köprülü and Ömer Lütfi Barkan but went beyond their findings. He continued the debate that Barkan had started on the social and economic transformation of the Ottoman Empire and focused his lens on rural as well as urban history. His firm belief in locating and making available Ottoman documents has had an enormous impact on the direction of the field from one that was philologically based to one that is also theoretically informed by the Annales school of French historiography among others. Professor İnalcık continued the debate that Barkan started on the social and economic transformation of the empire and focused his lens on the rural as well as urban history. His ability to acquire enough linguistic skills and grasp the works of Byzantinists as well as Balkanists made his contributions to the field even more important. He was able to understand the crucial aspects of pre-Ottoman history and trace continuity and change in a very effective manner. His findings on early Ottoman history are unquestionably also important for the medievalists in both Byzantine and Middle Eastern history. $\mathrm{He}$ helped organize one of the most important archives in the world, the Başbakanlık Archives in Istanbul and fought hard to open it to foreign scholars in the field.

At the University of Chicago, he worked with scholars like William McNeil and trained more than twenty students, many of whom have made an important impact in the field of Ottoman studies. Every week, a group of graduate students would line up before his office to receive his advice. He would start his paleography classes with documents that he would have us read and then will lecture on important terms like the 'kadi' for an hour. He had a passion for the archives that he instilled in us. Below, some of his former students will also share their own experiences with Halil Hoca.

(Fariba Zarinebaf) 
Professor İnalcık graduated from Teachers' College in Balıkesir in 1935 and was admitted to the newly established Dil ve Tarih-Coğrafya Fakültesi of Ankara University where he studied Ottoman history with the eminent historian Fuad Köprülü. After he graduated he remained as a Research Assistant and later Professor with the faculty, whose mission was to provide a scholarly framework for Atatürk's "Turkish historical thesis," an essential element in national identity and in the development of a new global status for Turkey. From this beginning Professor İnalcik acquired his conviction of the need to correct distorted views of the Turks prevalent in scholarly as well as popular writing. He developed skills in textual analysis through seminars with Paul Wittek in London, with a group of fellow students who later became leading Ottoman historians in their respective countries. A third influence was the institutional and socioeconomic emphasis of the French Annales school brought to Turkey by Ömer Lütfi Barkan.

Although heavily indebted to these scholars methodologically, Professor İnalcık retained a critical attitude to their conclusions, seeing their work as initial steps on a path that demands further development. His exploitation of the voluminous Ottoman archival and documentary records enabled him to supplement, verify, and critique the view of events presented in historical chronicles, expand the description of Ottoman institutions and their effects on the people of the empire, and better understand the empire's place in the larger Mediterranean world. Professor İnalcık's doctoral thesis, concentrating on the social effects of the nineteenth-century Tanzimat land reforms in Bulgaria, was the first of a series of works on landholding and agricultural production in the Ottoman Empire that include the publication of the earliest landholding register in the archives, that for Albania in 1432, a long series of articles on landholding and taxation, and culminating in his exposition of the basis of Ottoman landholding in An Economic and Social History of the Ottoman Empire, published by Cambridge University Press in 1994. Since that time scholars have published innumerable studies based on Ottoman landholding records that provide detailed information on population, agrarian production, taxation, and economic activity all over the empire.

Professor İnalcık's discovery of the wealth of economic information in the Islamic court records of Bursa, beginning in the 1460 s, led to detailed research on industrial production, trade, craft organization, and urbanism. Again, his example has been followed by historians in all the former Ottoman lands who 
are employing Islamic court records as a basis for local social and economic history. Professor İnalc1k studied many other documents relating to socioeconomic history, including a custom register from the Crimea and law codes regulating landholding, trade, and taxation. Moreover, he was instrumental in the preservation of the court records of both Bursa and Istanbul, which have become pilot projects for efforts to conserve, publish, and computerize the court records of Turkey as a whole. In the 1970s Professor Inalcik founded the International Association for the Social and Economic History of Turkey. This organization's triennial meetings bring together researchers in Ottoman history from all over the globe. To promote research in Ottoman history, Professor İnalcık initiated or supported efforts toward the systematic publication of archival documents such as the registers of governmental edicts (mühimme) and revenue surveys (tahrir), as well as several journals devoted to Ottoman studies. At Ankara University from 1943 to 1971 , at the University of Chicago from 1972 to 1986 , and finally at Bilkent University, Professor İnalc1k has trained generations of students to follow in his footsteps, using detailed archival research and critical textual study toward a clearer elucidation of Ottoman history and institutions and a better understanding of the empire's place in the wider world.

It was a privilege to have been mentored by Professor Halil İnalcrk, who is without a doubt the greatest Ottoman historian of the modern era. Not only is he unmatched in his readings and interpretations of the Ottoman language and Ottoman paleography, but, unlike most of us, he was also able to communicate effectively with other disciplines and historians, use their methodologies and historiographies, and convey to them the pertinence and example of the Ottoman world. He, more than anyone else, is responsible for the surging interest in the Ottoman empire in fields as disparate as Renaissance Studies, Economics, Imperial Studies, and Postcolonial Studies.

Linda Darling says: "Although I did not originally intend to become an Ottoman historian, I found Professor İnalcık's classes to be the most interesting and challenging courses in my graduate program, and so I became a convert. He knew so much and could recite it in detail, virtually without notes, providing names, dates, and bibliographical references. I found that he cared deeply about his students' work and generously shared references, offprints, and documents on any subject. Unlike some of my other professors, he was also in touch with important European historiographical trends and situated his material 
comparatively and theoretically; he was a truly global scholar. I soon learned that he had colleagues in many countries around the world with whom he was in constant interchange.

He tirelessly encouraged Ottoman studies in the Balkan countries and the Arab lands--after all, Ottoman history is their history, too--and in countries such as Austria and Russia which through historical chance have collections of Ottoman manuscripts and documents--and even in countries like America and Japan where diligence and wealth made for influential scholarship. He was always behind in his work because Ottoman historians all over the globe sent him dissertations and manuscripts to review, and because every major project in Middle Eastern history, from the Cambridge History of Islam to the Encyclopedia of Islam to each new journal in the field, sought him out as a contributor. In order to fulfill his intellectual obligations he amassed thousands of notes and photocopied documents on hundreds of different topics, stored methodically in envelopes, which he would pull out whenever he had to write an article or give a lecture. This habit was what enabled him to be so prolific and at the same time detailed and original. What made his example valuable to me is the standard he set for breadth and depth of scholarship, the combination of accurate detail and comprehensive scope, and a concern not just for one little corner of the field but for the health of the field as a whole."

Daniel Goffman wrote: "I came to Ottoman history quite late, having matriculated into the graduate program at the University of Chicago in early modern European history. I began my drift into Ottoman studies only in my second year and at the suggestion of another teacher, Arcadius Kahan. He reasoned that the very best historian at Chicago was Halil İnalcık, and that I should work with him for this reason and because of my love for archival work. I never looked back. Both intimidating and wonderful about working under Halil Bey was the sense that he himself was an Ottoman. The Ottoman Empire may be dead, but Halil Inalck is perhaps the last living representative of that society. I became aware of this fact very early, in the first paleography class I took with him. The three students in the class were attempting, without much success, to read an Ottoman decree from the late sixteenth century. Halil Bey saw our difficulties, wrote out the decree in his own hand, and told us to come back the next day with a translation. There was a problem, though. His handwriting was as difficult to decode as was the original. It was only later, while reading letters from the early twentieth 
century, that I understood that his Ottoman cursive was from that era; one of the most difficult of all Ottoman scripts.

Halil Bey was a real Ottoman. His exercise did work. By using one version against the other, and the second version against the first, I was able to come up with a rough translation of the decree, and take an important first step toward reading and interpreting these difficult materials. At a later point in my education, Professor İnalcık read a chapter from my dissertation. He told me that my interpretation of the events was wrong. I asked him why. He replied that he could not explain, but that the Ottoman world simply had not operated as I described it. Of course, after further reading and thinking, I realized he was right. One lesson I learned from that incident was that not only was Professor İnalckk a brilliant archivist, historian, and thinker, but also that he represented something that is priceless and irreplaceable: that is, he was perhaps the last representative of a great and deceased civilization. None of the rest of us can simply say "no, that is not correct" on the basis of personal experience combined, of course, with an unrivaled understanding of historical methodology, paleography, and interpretation."

Palmira Brummett states: "Professor İnalckk struck me, from the first, as a formidable scholar. That is why I chose him as my advisor, and, indeed, he proved to be a formidable mentor. What Professor İnalckk communicated in his seminars was that Ottoman history was endlessly absorbing, philology was immensely important, and understanding the intersections of economies and societies was the work of a lifetime. He taught us endurance, and the meaning of hierarchy. He worked us through our documents. After a seminar with Professor İnalcık, students used the word "document" in a different way. I absorbed some of my hoca's lessons better than others. But his influence on my scholarship has been far-reaching. He taught me to see beyond the notion of trade as a simple exchange and to probe its varied and intriguing dimensions. He developed my sense of appreciation for the historical contexts of events and for the meaning of "civilization." Professor İnalcık, for his graduate students, was also a human archive. I never posed a question that he could not answer by saying, "I remember some interesting documents on that subject." Often enough, he jotted a note on one of the numerous pieces of paper that he kept stuffed in his pockets and, the following week, he would produce a document illuminating the very question I had asked. As a scholar, I have long since abandoned the effort to duplicate İnalcık's impressive memory or his apparently tireless energy. But as 


\section{ZARINEBAF - DARLING \\ BRUMMETT - GOFFMAN}

part of the University of Chicago's scholarly silsila, I like to think I share some of the qualities Professor İnalckk, exhibited then: intense intellectual curiosity; attention to the historiographic question; and the delight in testing interpretative boundaries."

Fariba Zarinebaf says: "I last met Halil Hoca in Ankara on June 23, 2014. Together with Linda Darling and Oktay Özel, we visited him in his house at Bilkent University. We had a wonderful visit and a long conversation about the state of the field, our projects, the students we were training and the numerous projects he was working on. His desk had several piles of books on it. He loved to hear from his students and kept track of what some of us were doing. We also had a tour of the Halil Inalcık Center for Ottoman Studies at Bilkent University, where he preserved his notes, archives, and ongoing projects. In fact, he had become even more productive than when he was teaching. He gave us each a box full of his new books.

I used to call him from time to time in the morning when we would have a nice chat about what I was doing and seek his advice. He also loved academic gossip and had a great sense of humour and could be quite down to earth. He often invited us to his house for lunch in Istanbul and personally oversaw the preparation of the food. Sometimes, he would take me to lunch with the archivists to introduce me to them so that they would help me out. When I was teaching at Bilkent University together with Halil Bey, we often used to get together for lunch on Sundays and pour over a Ru'us register we were working on. It was a great honor to have been both his student and his colleague at Bilkent University. He created a great graduate program at Bilkent University, which has trained a good number of students, some of whom later joined leading graduate programs in the US. Halil Bey enjoyed mentoring students and was excited to learn about new research in the field. What impressed us most were the numerous projects he was still finishing up and publishing every year. Even though, I studied with him for several years at the University of Chicago, I still find myself referring to his articles foremost when I am writing a chapter or an article, especially on the history of Istanbul. Halil Hoca had an amazingly active mind and was never beholden to old paradigms and had a vision for Ottoman studies at home and abroad that he implemented with great success.

We will miss his intellectual energy immensely and will continue reading his valuable and innumerable contributions to the field of Ottoman history." 


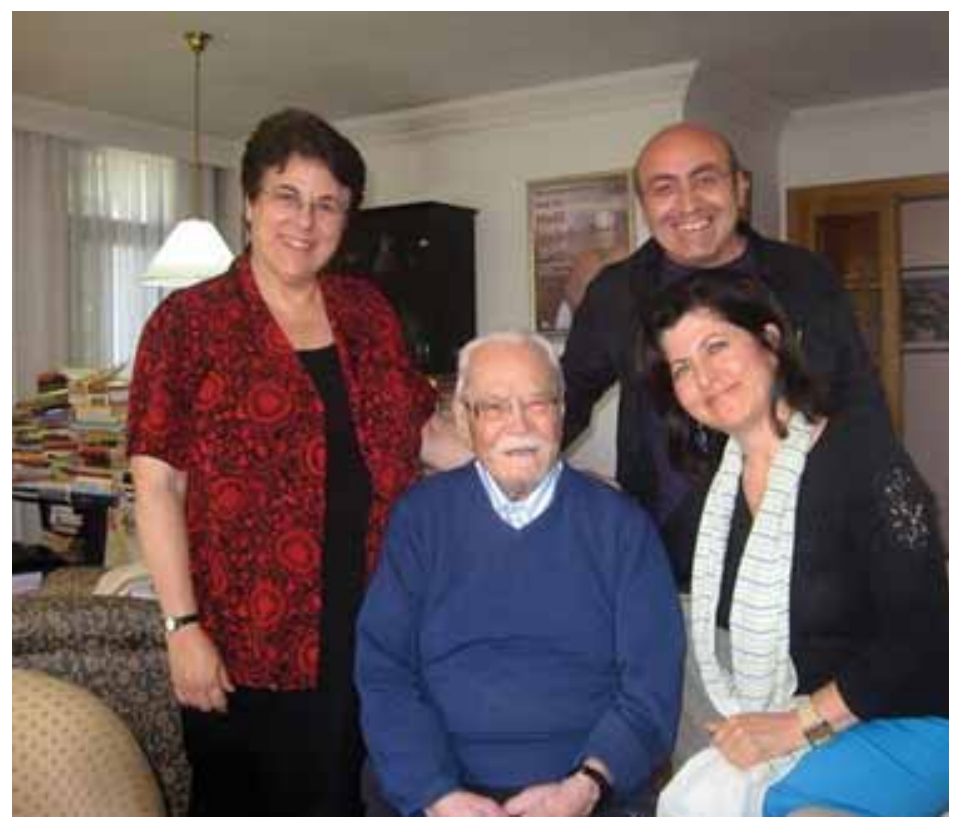

Halil İnalcık'n Bilkent'teki evinde, Linda Darling,

Halil İnalcık, Oktay Özel, Fariba Zarinebaf

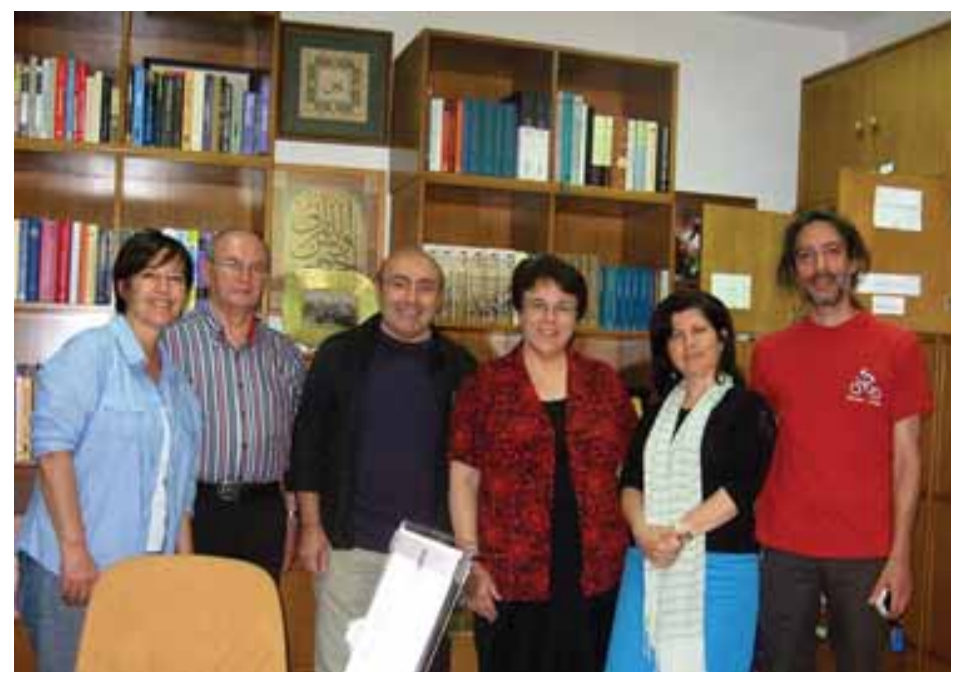

Halil İnalcık Osmanlı Araştırmaları Merkezi'nde (İhsan Doğramacı Bilkent Üniversitesi), Nil Tekgül, Özer Ergenç, Oktay Özel, Linda Darling, Fariba Zarinebaf, Kayhan Orbay 